\title{
Cambridge as a Place in Economics
}

\author{
Maria Cristina Marcuzzo, Nerio Naldi, \\ Annalisa Rosselli, and Eleonora Sanfilippo
}

In a letter to John Neville Keynes, in an attempt to persuade him to decline the offer of a chair in Oxford and to remain in Cambridge, Hubert Foxwell wrote in 1888: "It is much better that a study should be concentrated in a particular place. There arise many of these same advantages as in the localisation of an industry" (Harrod 1951, 9). In this article we propose to amplify this remark by investigating the nature and importance of Cambridge as a place in economics. Here we concentrate our analysis on the post-Marshall era, being of course mindful that prior to that era the term Cambridge school is synonymous with Marshall's economics and endeavors.

Cambridge capital controversy, Cambridge monetary theory of business cycle, Cambridge equation as a version of the quantitative theory of money - the geographical reference often crops up in the characterization of the economic theories and approaches that developed in Cambridge,

Correspondence may be addressed to Maria Cristina Marcuzzo, Universita' Degli Studi di Roma "La Sapienza," Dipartimento di Scienze Economiche, Via A. Cesalpino, 12/14, 00161 Roma; e-mail: cristina.marcuzzo@uniromal.it. We are grateful to the participants in the XI European Conference on the History of Economics (Paris, October 2006) and in the workshop held at Hitotsubashi University (Tokyo, December 2006), where an earlier version of this article was presented. We are particularly indebted to two anonymous referees for valuable comments and criticism. Thanks are due to King's College, Cambridge, for permission to quote from an unpublished letter by J. Robinson and to D. Papineau for permission to quote from an unpublished letter by Kahn.

History of Political Economy 40:4 DOI 10.1215/00182702-2008-027

Copyright 2008 by Duke University Press 
England, between the 1920s and the 1960s-including the contributions of economists who did not always share the same interests, backgrounds, or attitudes, but who all lived and worked for considerable periods of time in that particular corner of the world.

In this essay we have selected a group of economists and a span of time-essentially between the two wars, with a few encroachments in the years following the death of John Maynard Keynes ${ }^{1}-$ to reconstruct the Cambridge of those years and explore the space it represented for economics. It was not only a place, but also a play of magnetic forces, drawing together and driving apart, where ideas emerged from an environment formed through intense human and professional relations, a well-defined cultural tradition, and a way of its own of organizing work and study. We present the dramatis personae and the background to their actions (section 1), and then go on to consider the characteristics of intellectual and personal communication at Cambridge (section 2), on the basis of which we are led to define the Cambridge economists more as a "group" than a school (section 3). In section 4 we see how an outsider like Piero Sraffa fitted into this group, thanks to the human and academic characteristics of Cambridge. The final section is dedicated to some concluding but by no means conclusive observations that we hope will nevertheless help define Cambridge as a place in economics. ${ }^{2}$

\section{Setting the Stage}

In the period we take into consideration, there can be no doubt about who the dominant figure was: for background, mentality, and method of analysis, Keynes was the quintessential product of Cambridge culture. In fact

1. In many respects the death of Keynes, in 1946, marks a watershed between two important phases for economic theory as developed at Cambridge: in this article we consider the first and not the second, highly significant though it was, that followed in the 1950s and 1960s.

2. It is beyond the scope of the present article to compare Cambridge with other centers of excellence in economics in Britain and elsewhere. For an overview of the main differences with Oxford and the London School of Economics, see Coats 1967 and Tribe 2008.

3. Keynes belonged to a family of the Cambridge intellectual bourgeoisie. His father, John Neville, philosopher and economist, was university lecturer in moral science at the University of Cambridge (1884-1911) and subsequently was university registrar (1910-25); his mother, Florence, much engaged in public life at the local level, was also to become mayor of Cambridge (1932-33). The committed activism of his mother-a heritage of the Quaker tradition-and, more generally, the dedication to public affairs characteristic of the Keynes family have been defined as the "civilisation of Harvey Road," from the name of the road where the family lived (Harrod 1951, 4-5, 192-93). On the sense of duty inherited by Maynard from his mother, see also Skidelsky 1983, 57-58. 
Keynes was born, ${ }^{3}$ studied, completed his education, and taught in Cambridge; he played an active role in the life of the college to which he belonged and whose bursar he remained for many years, namely, King's; he was also the founder of the famous Political Economy Club-later known simply as the Keynes Club-a close circle in which young students and researchers discussed economics (see section 2 below; Skidelsky 1992, 5; and Moggridge 1992, 188-89). Keynes lived many long years in the city, even when his various commitments obliged him to spend several days of the week in London. He was a moving spirit behind the academic and cultural life of Cambridge, and notwithstanding travels and various activities that also took him abroad, he maintained strong ties with the city and the university. ${ }^{4}$ In terms of theoretical research, his criticism of the traditional theory of income and employment (Keynes 1936) arguing the nonexistence of automatic mechanisms that lead the system toward a condition of full employment-represented a turning point in economic theory and a fundamental benchmark in macroeconomics.

Alongside Keynes was another personality who left his indelible mark on the Cambridge economics of those years: Piero Sraffa, rescued from the strictures of Mussolini's Italy - thanks to Keynes's timely interventionby the University of Cambridge. With his critical articles intent on exposing the logical flaws of the Marshallian theory of value (Sraffa 1925, 1926) and his head-on assault on the analytic foundations of the neoclassical theory of value and distribution (Sraffa 1960), from the mid-1920s through the 1960s and on, Sraffa became a fundamental reference point for criticism of marginalist theory, and he constitutes a particular example of that critical spirit so characteristic of Cambridge.

Around them was a whole array of famous economists including Arthur Cecil Pigou, Dennis Robertson, Gerald Shove, Richard Kahn, Joan Robinson, Maurice Dobb, Austin Robinson, and, later, Nicholas Kaldor, as well as some rather less famous, such as Hubert Henderson, Frederick Lavington, John Clapham, Ryle Fay, Claude Guillebeaud, and Marjorie TappanHollond.

With the exception of those not born in the United Kingdom, all these economists were products of Cambridge, in the sense that they were Cambridge-educated. As Austin Robinson $(1992,206)$ recalled in his reminiscences of economics studies in Cambridge, in "those days one 'read'

4. A curious topographic fact of Keynes's life in Cambridge was that it was effectively spent in an area bounded by Harvey Road (his parents' house), Mill Lane (where the lectures were held), and King's (his college). 
a subject: the emphasis was on reading a half-dozen books, nearly all of them written in Cambridge. One acquired one's capacity as an economist from them. One read other books for information." And there is the famous remark by Keynes that all one needed to be a good economist was a thorough knowledge of Marshall's Principles and careful daily reading of the Times (Harrod 1951, 324). For many of these economists, Cambridge remained the center of their entire existence.

What was it, then, that generated this Cambridge milieu in the world of economics? Where lay the source of this teeming torrent that gave rise not only to the two fundamental approaches-the Keynesian and the Sraffian-but also to many other theoretical currents of outstanding significance? We might mention, for example, the theory of imperfect competition, with vital contributions from Sraffa himself (1926), as well as Kahn (1937, 1989), Joan Robinson (1933), Shove (1933), and Austin Robinson (1941), or the monetary theory of the business cycle (Lavington 1922, Robertson 1926, Pigou 1927), or, yet again, industrial economics (Robertson 1923). Both the latter developments followed the lead from Marshall $(1919,1923)$, who is rightly considered as the founding father of Cambridge economics (Becattini 1990).

One force that catalyzed intellects and stimuli lay precisely in the faculty of economics and politics of the University of Cambridge. The faculty saw the light thanks to Marshall, who had in 1903 succeeded in the face of competition from other academic and geographic realms (like Birmingham and London) in instituting the tripos in economics (see Collard 1990, 167-68; and Tribe 1997, 10-11). It was in fact Marshall who had first believed in the possibility of making economics an independent discipline, and indeed a major one in the academic system of a Cambridge hitherto dominated by classical and mathematical studies (see Coats 1993, 106-13; Groenewegen 1995, chap. 15). It was basically Marshall who set the process moving and supported the birth of the faculty, also at the level of organization, selecting the teaching staff and courses, guiding and coordinating the academic life and assignments of the various members, and even paying (out of his own pockets) young lecturers (such as Pigou and Keynes, to name just two). And a few years later it was his pupil, Pigou, who took over his role, making a decisive contribution-both quantitatively and qualitatively - to the development of the faculty. The operation proved an unqualified success, seeing that just a few years later-that is, from the 1920s-Cambridge came under the attention of the rest of the world as a paragon for the study of economics, while those engaged 
there in research and teaching had a distinct sense of belonging to a concentrated microcosm with a clear identity of its own. Some idea of the image Cambridge had in terms of economic theory can be gained from a letter of July 1928 by Robertson to Keynes, referring to the proofs of Dobb's Wages (1928) published in the Cambridge Economic Handbooks series that had Keynes, and subsequently Robertson, as editors: "I think it's very regrettable if the theoretical part has to be merely descriptive of what various people have said, for people will look to a Cambridge book for analysis" (Keynes Papers, L/R/45-48; quoted in Sanfilippo 2005, 64; emphasis added).

Marshall and his works represented the major theoretical reference point for all that generation of economists; all had to reckon with Marshallian theory, whether to go on to take a distance from it, or to forge ahead along the most original and promising lines of research it offered. When Marshall retired in 1908, the chair in political economy went to his "natural" successor, Pigou, who remained for many years the only professor in economics on the entire faculty. At the beginning of the 1920s, the main economic theory course was given by Pigou on the basis of the "bible"Marshall's Principles - while the three lecturers were Shove, Lavington, and Robertson. Henderson and Keynes lectured on monetary policy and theory, Guillebaud on trade and finance, and Tappan-Hollond (the only woman on the faculty) on monetary systems. Finally, as indicated in the Cambridge University Reporter, Dobb and Austin Robinson-the younger generation-held courses called, respectively, The Function of the Entrepreneur and Money, Credit, and Prices.

From the early 1930s the situation in the faculty had changed thus: Robertson had become reader and gave the course on money; Keynes taught The Pure Theory of Money (1931-32) and The Monetary Theory of Production (1932-34), which paved the way to the General Theory. Shove-who had become Girdlers' Lecturer in 1928-held courses called Production, Value, and Distribution and Wages and Prices; Kahn was giving a course titled The Short Period; Dobb taught Social Problems and Labour; and, finally, Austin Robinson taught Current Economic Problems and Money, Banking, and International Trade. Sraffa-after a brief period as lecturer (1927-31) - became assistant director of research in 1935 (see Marcuzzo 2005, 432-33), exerting considerable influence within the faculty and-in what was known as "Sraffa's seminar," designed in particular for PhD students-on the students engaged in research. In 1934 Joan Robinson was made assistant faculty lecturer, and at one point she 
was under fire from the other members of the faculty (in particular Robertson, Fay, and, to some extent, Pigou), Keynes representing her only support (see Naldi 2005b). Her opponents censured what they saw as an overtly critical-if not disparaging-attitude toward traditional economic theory, taught (and held valid) by other authoritative members of the faculty. Significantly, it was only in 1938 that Joan Robinson finally obtained a university lectureship. Actually, in the second half of the 1930s (after the publication of the General Theory), she played a fundamental role at Cambridge with her ability to carry through the "Keynesian revolution" at the theoretical and academic level, showing an exceptional capacity to integrate it with theoretical elements from external sources (such as Kalecki's theory).

Cambridge was a world that could prove practically impermeable: one might be co-opted into it, as was the case with Sraffa (see section 4), but also rejected, as was the lot of Hicks. Unlike Sraffa, Hicks never mingled with the Cambridge group (see Marcuzzo and Sanfilippo 2008). In 1935 he left the London School of Economics to take up a post as lecturer at the faculty of economics in Cambridge, for which Pigou had warmly invited him to apply. ${ }^{5}$ It has been argued (Hamouda 1993, 19-20) that Hicks had been appointed, under the influence and initiative of Robertson and Pigou, to rein in Joan Robinson, who was all too obsessively propagating the Keynesian creed. What seems more likely is that Pigou, eager to maintain a certain degree of "academic pluralism," favored Hicks's election in the interest of achieving readjustment between the different orientations within the economics faculty, as well as counteracting Robertson's growing isolation. In Cambridge Hicks $(1982,127)$ felt "much closer to Robertson than to any other economists" among his seniors, not only from a theoretical point of view, but also at a personal level. Robertson felt psychologically supported with Hicks's arrival in Cambridge, and it appears no coincidence that both decided to leave Cambridge at more or less the same time, in autumn 1938, Hicks for Manchester University and Robertson for the London School of Economics. Hicks-educated in Oxford and coming from the LSE of Lionel Robbins-never felt, during his stay in Cambridge, to be part of it. In lifestyle and conception of economics he could not be more apart. Keynes's attitude, not particularly enthusiastic-exactly the opposite than it was in Sraffa's case-also played

5. In that year Hicks taught the courses Principles of Economics, Labour Problems, and, later in 1937, Some Leading Continental Economists. 
a role and did not favor his integration. When Hicks arrived in Cambridge, the General Theory was going through the final stage, but in no way was he involved in the process of final drafting of the book (see Marcuzzo and Sanfilippo 2008, 82). Hicks's permanence in Cambridge did not change Keynes's attitude, since at the time of Hicks's departure Keynes's opinion of him as an economist ${ }^{6}$ and as a teacher ${ }^{7}$ was still quite negative.

At the time of Keynes's death, the faculty and staff included Shove as reader (a role he had taken in 1945); Robertson as professor of political economy (from 1944) in the place of Pigou (retired); and Austin Robinson, who was to gain a professorship a few years later and who had taken on an increasingly important role, joining Keynes as coeditor of the Economic Journal. Joan Robinson, together with Kahn (after the war) and Dobb, was still busy teaching. ${ }^{8}$ The number of people teaching courses remained relatively small (ten lecturers and a faculty assistant lecturer), but the courses and students had increased in quantity. And by the end of the 1940s there was also a Department of Applied Economics, with Richard Stone appointed director in 1945.

But what exactly was the role of the faculty itself? Through its official bodies, such as the faculty board (with associated Appointment Committee and Lecture List Committee), responsible for major decisions regarding faculty management, and the Degree Committee, which decided on admitting students to the various graduate degrees and assigned (and changed) theses and supervisors, the faculty set the general guidelines with its choice of official courses and structuring of the degree course (Marcuzzo 2005, 434-36). It was with the experience of active supervision that the new generations were formed, knowledge effectively transmitted, and personal and academic relations drawn closer (see section 2). The faculty was in an arena where very different positions could come in for comparison or contrast: in the 1930s, on the one hand there were

6. After reading Value and Capital-a book conceived and partly written by Hicks in Cambridge-Keynes wrote to Kahn on 11 April 1939: "I don't think I have ever read a book by an obviously clever man, so free from points open to specific criticisms, which was so utterly empty" (Kahn Papers, 13/57/411, quoted in Moggridge 1992, 553).

7. On 15 June 1939, the year after Hicks's departure for Manchester University, Keynes wrote to Pigou: "I'm just at the end of the Tripos examining. The general standard is lower than anything I have previously struck for Part II. . . Hicks's teaching of the Principles has, I think, definitely confused the men and put them further back than as if they had had no such instruction" (Keynes Papers, EJ/1/6/5-7, quoted in Sanfilippo 2008, 81).

8. According to the Cambridge University Reporter, Joan Robinson became reader in 1949 and professor only in 1965, when Austin Robinson retired. Kahn became professor of economics in 1951, Dobb a reader much later, in 1959. 
the orthodox Marshallians-part of the "old generation"-including Pigou, Robertson, and Shove-while on the other hand the younger contingent, including Kahn, Joan Robinson, Dobb, and Austin Robinson, looked to Keynes and Sraffa as reference points. To see how this distinct group of personalities achieved concrete interaction, combining to form a unicum in the history of economic thought, we must take a closer look at the geography of the place where these economists lived and worked for the best part of their time.

\section{The Geography of Cambridge}

How was it, then, that geography-the structure of the place-could influence relations within the group-the sense of belonging its members shared and the way they communicated with one another?

When we come to consider how Cambridge was structured in the interwar period, what strikes us first is the contrast between the opulence of the colleges-splendid halls and common rooms designed to favor socialityand the relatively cramped spaces reserved for the activities of the university, and of the economics faculty in particular. A critic of Cambridge life wrote that "one had very little, if any, regular contact with other Faculty members outside of one's own College" (Johnson 1978a, 90). Just ten days after he arrived in Cambridge at the end of September 1935, Hicks noted in a letter to Ursula Webb (later his wife): "This evening I have at last been seeing some economists" (Marcuzzo et al. 2006, 15). A somewhat extreme case, perhaps, but the truth is that much of the social life and teaching (given and received) still revolved around the colleges.

What distinguished the Cambridge didactic system was the personal relationships established with the students and the close attention given to their selection and education. Some of the personal rapport of respect and friendship that characterized the interaction between the economists we are interested in here began as relations between supervisor and student (as in the case of Keynes with Robertson and Kahn; Robertson and Shove with Austin Robinson). Even the relationship of Marshall with Keynes and Pigou had begun as a relation between teacher and pupils. They both attended Marshall's lectures and, although Marshall did not formally supervise students, he used to give them questions and was "at home" for them six hours a week (Groenewegen 1995, 313, 316).

Although these personal relations had little to do with the university organization, they were above all the product of teaching in the colleges. 
The lectures given by those who had university appointments were few, extremely formal, almost always based on a written text, ${ }^{9}$ and therefore fairly unrewarding if the lecturer had no great gift for writing or exposition. Many recalled the sheer boredom of the lectures given by Dobb, Guillebaud, and Shove (Johnson 1978b, 129; A. Robinson 1977, 28).

In the interwar period, a lecturer's standard workload consisted of two courses of sixteen lectures in the first two terms, plus another short course in the May term. The lectures entailed no personal exchange: the students asked no questions..$^{10}$ The lectures were held in the Mill Lane halls, shared with other disciplines: more like a theater than a meeting place for the teachers. The faculty itself had the scantest of premises, most of its few rooms being occupied by the Marshall Library. Until they moved to the new buildings on Sidgwick Avenue together with the library in the 1960s, the faculty rooms rarely served as meeting places.

It was the college supervisions that constituted the heart of the didactic system, taking up many hours of the dons' time: in 1935 Hicks was supervising no fewer than eighteen students of his college, Gonville and Caius, and one outsider. ${ }^{11}$ The supervisions varied in length and frequency, but usually were an hour each week; they were given individually or to very small groups by members of the college itself if it had a tradition of economics teaching-above all King's (which Keynes, Pigou, Shove, and Kahn belonged to) and Trinity (Robertson and, later, Sraffa and Dobb). Economists lacking college fellowships, like Dobb until 1948, also collaborated on the supervisions, thereby rounding out their university salaries. The supervisions were based on essays submitted by the students. The don's task was often precisely that of inducing the student to clarify the terms employed, ${ }^{12}$ following a pattern that was so ingrained as to be extended also to debate with colleagues (see, for example, the debate in

9. We have ample evidence of the fact that lectures were prepared in written form (see, for example, Johnson 1978b, 129), and some of the texts or notes have survived-for example, the lectures by Kahn (Kahn Papers, 4/13 and 4/14); and by Sraffa (Sraffa Papers, SP D2/4); and, of course, by Keynes.

10. This explains why Sraffa's style of lecturing appeared rather unusual: "Joan Robinson, who attended the lectures on her return from India, recalled them vividly, not least because Sraffa liked to develop a dialogue with his class" (Eatwell and Panico 1987, 446).

11. Letters from John Hicks to Ursula Hicks (then Webb) of 8 and 9 October 1935, in Marcuzzo et al. 2006, 12, 15. Ursula was worried about Hicks's "pretty heavy time table" (letter of 10 October 1935, 19) and reported Robbins's concern that Hicks was overworked (letter of 14 October 1935, 24).

12. According to a pupil in 1928 , Keynes "wasn't satisfied with any of our papers because we did not say 'what one feels one means' by the word 'capitalism"” (Plumptre 1975, 248). 
1944 between Joan Robinson and Shove on the meaning of "waiting" as origin of profit ${ }^{13}$ between Kahn and Harrod on "saving" in OctoberNovember 1934; ${ }^{14}$ and between Joan Robinson and Kaldor on "employment, prices, real wages, the rate of interest" in June 1935). ${ }^{15}$

Relations with students were no secondary matter, since academic clout was also measured by the possibility of choosing the best students, who would be actively involved in the ongoing debates. As Austin Robinson $(1977,33)$ observed: "Throughout that period they [the best students] were playing a very considerable part, and by no means a merely receptive part, in the furore of argument that was going on." Visiting Chicago in 1933, Kahn was shocked by the contempt shown toward the students at the university there, writing to Joan Robinson on 15 January: "Perhaps the most peculiar thing about my stay here is that after a fortnight I have met scarcely anyone who can tell me anything about the education of the undergraduate. He is universally regarded as an excrescence, fit only for menials to deal with. But I am persevering in my search. The pundits all lecture four times a week, but only to graduates" (Kahn Papers, $13 / 90 / 1 / 44-51){ }^{16}$

Moreover, the Cambridge teaching staff were united by what they saw as a mission, namely to educate a ruling class that would, on the strength of reason and "sound" theory, be able to govern in the best possible way. As Austin Robinson $(1992,205)$ recalled: "Pigou, the complete Marshallian, always regarded economics as a subject one studied not for itself, but for the benefits it might bring. And this was the prevalent outlook of virtually the whole of the Cambridge staff of the period." Ultimately, a great deal was seen to be at stake, which accounts for both the fierceness of the clashes and the spirit of proselytism that characterized the work of, say, Kahn, or Joan Robinson. A former pupil gave a very telling account of his experience of being supervised by Joan Robinson in the early 1950s: "She expected that we would immediately see the point and become her allies in a godly crusade against the dragon of neoclassical orthodoxy-

13. See letters from Joan Robinson to Shove of 5, 10, and 30 May 1944 and from Shove to Joan Robinson of 12 May 1944 (Keynes Papers, L/44/21-39); see also Rosselli 2005, 364-65.

14. See the reconstruction of the debate in Besomi 2000, 358-68.

15. See the letter from Joan Robinson to Kaldor of 3 June 1935 (Kaldor Papers, 1/9/16-18); see also Rosselli and Besomi 2005, 317.

16. A less parochial, but perhaps not less unbiased, account of teaching style in Chicago can be found in Reder 1982, 8-9. 
which she saw as ideological tear-gas, blinding us to all the worst features of a capitalism she hated with the enthusiastic zeal of a true believer" (Waterman 2003, 593-94).

It was necessary to win over the hearts and minds of the students, and of the best students in particular. This was accomplished not only with lectures and supervisions-always conducted with some formality-but above all with debate in the two meeting grounds Cambridge offered economists in term time: the Marshall Society and Keynes's Political Economy Club. The Marshall Society, which usually met once a week in the room above the Marshall Library, was closer to what we would now call a seminar; it was open to all and attended by undergraduates; members of staff, but also, quite often, guests from round the world would present their work, and all could contribute their views, at times with fairly scathing criticism. Joan Robinson, a great debater, attended the Marshall Society assiduously in the 1930s. Some idea of just how heated the debates could become can be gathered from the account of a meeting in a letter dated 3 March 1933 that she wrote to Kahn, describing the presentation of a paper by a certain Coates: "Mr. Coates turns out to be even nastier than he is stupid and stupider than you could believe. I baited him scandalously to the unconcealed delight of the Marshall Society. Towards the end there were shouts of No, and loud laughter at everything he said" (Kahn Papers, 13/90/1/168-9).

The Political Economy Club was a markedly elitist reserve where students could exercise their intelligence to the full. Founded in 1909, it met every other Monday in the evenings in the handsome rooms Keynes occupied at King's. Admission was solely by invitation, extended after careful selection, academic success being only one of the criteria. ${ }^{17}$

Public debate and discussion were founding elements in the life of Cambridge and the education of her students. As an undergraduate Keynes belonged to about ten debating societies (Marcuzzo 2006, 133 n. 2). And Marshall, when he instituted the economics tripos, had a clear idea of the ideal education that Cambridge (and Oxford) could offer. As he said in his address to the senate of Cambridge University on 7 April 1902, "Other institutions can give a technical training, suitable for the lower ranks of

17. Consider, for example, a letter that Harrod (2003, 299-302) wrote to Kahn on 15 October 1934, probably on the request of Kahn (or Keynes) for information about an Oxford student who had not gained the DPhil: "I cordially recommend Smith for Maynard's club. He is a really intelligent man and always makes a good contribution to a discussion. I think you would find him quite an acquisition." 
business more easily than we can, and with less harm to themselves. But we are well placed for giving a broad education which will bear directly on the larger management of affairs, and for adding to it that training of personal character which is offered by life at Oxford and Cambridge" (Marshall 1902, 432). ${ }^{18}$

Apart from these two forums for public debate (one of which was not all that public), few opportunities were organized in Cambridge for meeting outside the colleges (the faculty board meetings were important, although restricted to the most senior members of the faculty, as were the meetings dedicated to organizing and revising the tripos questions). Isolation was therefore relatively easy to achieve: the economists were scattered throughout the various colleges, when they belonged to one, and could always retreat to the privacy of their own rooms, if they wished to do so. Pigou, for example, had opted for such isolation, as had to some extent Sraffa. In the interwar period Dobb $(1978,119)$, too much involved in his political work, by his own admission stood apart from most of his fellow economists and their theoretical discussions. Thus one might never find oneself having to talk economics with certain colleagues.

What, then, was the origin of that intense interchange that characterized Cambridge through the 1960s? Exactly what kind of intellectual collaboration was it? In Austin Robinson's reminiscences $(1992,36)$ of the 1930s, individual ownership of ideas was regularly denied: "Where a small group is constantly arguing together, arguing with their pupils and arguing with others outside, one seldom knows exactly who was initially responsible for which elements in the collective thinking, and any one person may be transmitting collective rather than individual ideas." But then there was also the well-known rivalry between Kaldor and Joan Robinson in the 1950s and 1960s over the "priority issue" of the Cambridge theory of growth and the debate on capital (Thirwall 1987, 160).

To begin with, once it was accepted that one might break in on another's privacy, opportunities to meet were actively pursued: "We constantly dropped in on each other," said Austin Robinson (1977, 32), as many letters confirm (Marcuzzo and Rosselli 2005). Belonging to the same college eased encounters when approachability mattered, bearing in mind of course that in the early period only King's had more than one economist. Kahn had been chosen by the members of the Circus for the role of gobetween with Keynes precisely because, being a member of King's, he had 
better opportunities to meet him. Moreover, being in the same college created a sense of belonging that favored greater openness and familiarity. ${ }^{19}$

Above all, however, economics was not talked about, it was written about. With the lack of telephones (at least until World War II), which were not installed in the college rooms or were flatly refused by the older generation, ${ }^{20}$ and the risk of wasted effort walking or cycling to call on someone who might not be in, written communication was an attractive option. Moreover, it was most efficient, three deliveries daily being guaranteed by the public postal service, while the colleges also had their own internal post. We owe to Harry Johnson (1978a, 95) a vivid description of his exchanges with Joan Robinson in 1946: "She would send me a handwritten note in the morning, and I would scribble an answer by noonday; and then I would get a note back in the evening saying, 'Where you made your mistake is as follows ...' I could keep that up for two days, but I soon wearied of the game." Many of these exchanges have been lost: we still have those involving Keynes, and some episodes illustrate the intensity and speed of the cut and thrust. Typical, too, is the fact that exchange was not only two-way, but the letters would be passed on to others who might then join in the debate. Thus there flourished in Cambridge an intermediate form between academic writings and oral exchange, and, informal as it may have been, this type of written exchange meant a measured approach in dialogue while encouraging the sharing of ideas even as they were finding expression.

\section{Group or School?}

Thus intellectual sharing was a major characteristic of the group of Cambridge economists considered here, and in particular of that subset sometimes called the "Cambridge school" (Keynes, Sraffa, Kahn, Joan Robinson, and Kaldor). ${ }^{21}$ Here we see a special type of partnership based on the frequency and intensity of communication, which was a long way from

19. When some members of the faculty board opposed the appointment of Joan Robinson as full-time lecturer in 1938, Fay wrote to Pigou, Keynes, and Shove. On 2 March 1935, he wrote, "My dear Keynes, I am writing only to old friends at King's, and therefore can speak more frankly than I otherwise would" (Kahn Papers, 14/99/209-14).

20. Keynes's dislike for the "inconsiderate" use of the telephone, which could interrupt him while at work, is clearly expressed in a letter to the New Statesman, 23 December 1922 (Keynes 1978, 100-101).

21. Leontief $(1937,337)$ coined the term "neo-Cambridge school" to distinguish it from the earlier generation of Marshall's followers, but it was not taken up in the literature. 
the coauthorship or the type of academic socialization typical of our days. The kind of communication we are looking at here did not always imply agreement on the premises or conclusions, but simply meant accepting the plane of discussion, that framework within which interaction waxed strong. And the interaction was there because criticism was generally constructive-given and taken, that is, because it found expression through personal and intellectual relations that cohered in other respects.

When we go on to consider how communication was actually conducted between certain of the protagonists, we find a diverse range of situations, from full interaction (as between Keynes and Kahn, or between Kahn and Joan Robinson) to the practically impossible (as between Kahn and Sraffa, or between Joan Robinson and Robertson) or highly confrontational (as between Joan Robinson and Kaldor in the postwar period). Along with many cases of communication having happy issue, there were others that led to open dissent (as was the case of Sraffa with Joan Robinson, or Robertson with Keynes) or reciprocal misrepresentation (as, for example, between Pigou and the Keynes of the General Theory) - one of the reasons why we cannot speak of the Cambridge approach to economics as a common project.

Unlike Pasinetti (2007), who sees Joan Robinson, Richard Kahn, Nicholas Kaldor, and Piero Sraffa as unquestionably having formed "a powerful school on the track of Keynes's economic theory" (61), we see these economists better characterized as a group than as a school. And indeed Pasinetti himself is the first to recognize that this "school" was in reality a motley, argumentative group united and divided by strong emotional bonds, although he discerned "something ... much deeper, that shaped their intellectual affinities or attractiveness and at the same time gave rise to their strong and stormy personal relationship" (Pasinetti 2007, 63). That "deep something," Pasinetti argues, derived from adopting a common approach to economics.

A Cambridge approach, then, was not so much a quality that they all shared but a bequest, an approach to economics that later economists took up.

Unlike a school, a group does not subscribe to a common body of doctrine, although there may be internal cohesion and shared contents. ${ }^{22}$ In a

22. There is more than one definition of what constitutes a school in economics. For an interesting discussion of this issue in February 2005, see the HES list archive: http://eh.net/ pipermail/hes/2005-February/thread.html. 
collection of essays from which some of these considerations were drawn, we used the metaphor of the interlocking rings on the flag of the Olympic games to evoke this particular way of belonging (Marcuzzo and Rosselli $2005,15)$ : positions intersecting on some planes and for certain individuals, rather than a "daisy" with petals radiating about a common center.

This group identity stemmed from motivations, values, lifestyles, and work styles, leaving room for reciprocal respect, overriding many contrasts, and keeping the sense of belonging alive. And the points of theoretical division, precisely because they generated discussion, did not break the group up but served to form a connective tissue. It was actually a matter of belonging to a place; Robertson, in a letter to Keynes dated 28 August 1936, even coined a term to define it-Cambridge-y (Keynes Papers, L/R/117-20).

Many of the economists considered here were notoriously disinclined to open up to the outside world; they did not suffer gladly differences from their own social and cultural context, which brought on them accusations of sectarianism. Sectarianism is indeed an ingredient of a certain form of overly narrow belonging, and as we know, it often generates intolerance. Probably the sectarian spirit of the Chicago school in the 1940s and 1950s was even narrower in excluding and opposing positions not aligned in defense of the market. ${ }^{23}$ In the case of the Cambridge group, on the other hand, precisely because there was no common corpus of accepted ideas to defend, the characteristic feature seems rather to have been elitism-a system of co-optation based on characteristics that were part of neither an ideology nor exactly of academic performance or success, but rather of a moral and intellectual aristocracy. The respect that Shove-a notorious underachiever who had published very little-enjoyed in the group (Rosselli 2005) cannot otherwise be explained. Much the same applies to Pigou, whose ideas were equally distant from the Marshallian tradition of Robertson and Shove on the one hand and the Keynesianism of Kahn and Joan Robinson on the other.

This recognition of a moral and intellectual aristocracy explains how Sraffa managed to integrate with the group on the personal and intellectual level, although in terms of economic viewpoint, political posi-

23. Viner himself, in a letter to Don Patinkin, acknowledged that the Chicago school, "engaged in organized battle for laissez-faire and the "quantity theory of money," was "not confined to the economics department and not embracing all of the department" (Reder 1982, 7 n. 19). 
tion, and cultural background, he could not have been further from the economists with whom he was subsequently identified as part of the Cambridge school. The respect and, at times, real accord between Robertson and Sraffa, who had nevertheless shown on the occasion of the symposium of the Economic Journal of 1930 just how radical their disagreement on the economics of Marshall was (defended to the hilt by one, "discarded" by the other), are to be appreciated at a level entirely different from that of acceptance of a common understanding of economics.

Some of the characteristics we have described in relation to the Cambridge group were not confined to the economists, but the issue that interests us here is a matter of the characteristics defining that manner of belonging. To this end it might help to consider the differences between groups, schools, and networks. The discriminating point is whether or not there is a sharing of common times and spaces.

If we consider the traditional way schools of thought are defined in textbooks or in historical research, we find examples of intellectual sharing and endorsement that consist in adopting a particular type of theoretical approach that takes on the form-albeit with occasional distortionsof a tradition to conserve, or a mindset acquired by pupils or disciples from a recognized leader. We might cite, for example, the Ricardian or Marshallian schools. Since a school is identified by shared approach and doctrinal content, we can speak of schools of thought also in the absence of unity of time and place, as for example when adherence is declared to a current of thought, tracing it back to the illustrious predecessors or "fathers" to endow a new theoretical approach with authority (to take two examples, the Austrian and the neo-Schumpeterian schools). In these cases what matters are the lineage and the ideal link, which has nothing to do with shared place or time.

There are forms of belonging, however, that have no need of unity of place. Groups formed from academic or professional networks display characteristics closer to those of a school than to a group, the individuals being united through shared ideas or professional practices (for example, the American institutionalists or the quantitative economic historians who gave rise to cliometrics).

There is another reason that argues in favor of defining the Cambridge economists as a group, on the basis of place and time, rather than as a school, with shared ideas and a recognized leader. The personal makeup of neither Keynes nor Sraffa was suited to the role of "master," and both had scant inclination to enlist disciples. It emerges clearly from the study of the correspondence that Keynes chose his interlocutors with a view to 
a possible meeting of minds, and they were always treated as equals, whether senior (like Pigou) or pupils (Kahn and Robertson) (Marcuzzo and Rosselli 2005). And when in section 4 we come to consider Sraffa's career as assistant director of research, the difficulty he experienced in forging professor-pupil relations emerges equally clearly: in a period of about thirty years, only one student successfully completed his $\mathrm{PhD}$ with Sraffa as supervisor (Marcuzzo 2005, 435).

The sort of belonging we have defined as characteristic of these Cambridge economists is not typical of all economists (we are more likely to find such belonging in literary or artistic groups, where shared places and time count), but it is probably typical of Cambridge, although no comparative study with respect to other scientific communities has yet been made. It would also help to have a better understanding as to whether Chicago, Vienna, or London-places where traditions of conducting economics were created or propagated thanks to the influence of certain authoritative protagonists and their proselytism - showed characteristics similar to or different from Cambridge: not, of course, in terms of contents, but in the experience of belonging.

In conclusion (provisionally, pending further research on the subject), the characteristics of the Cambridge economists as group rather than school seem to lie as follows:

- In the particular type of communication-written and oral-that led to very close forms of interaction, not devoid of diversity and dissent.

- In the physical and temporal closeness, helped in part by relatively unconventional lifestyles upon which profound personal ties were threaded and woven.

- In the personal characteristics of Keynes, who gave the Cambridge economists an intellectually hegemonic position, but at least in his lifetime did not make him the leader of a school. In the case of Sraffa, the aspect of intellectual hegemony was more limited-though no less intense-and even more total was the absence of explicit proselytizing, although the Sraffians are perhaps by now the school most closely identified with the heyday of Cambridge economics.

\section{Becoming Part of Cambridge}

We can highlight some of these characteristics - the importance of discussion that does not necessarily lead to convergence on the same position, the centrality of the relationship with Keynes, the personal rapport 
that overrides differences of opinion-by taking the particular case of Sraffa. Our focus will concentrate on two main aspects: (1) the differences and the similarities between the environment where Sraffa was brought up and educated as an economist and the Cambridge environment, and (2) the ability of Cambridge-including its university, its faculty of economics, its colleges, and our group of economists - to integrate a person who, nevertheless, was able to maintain a critical attitude toward the work of that very group, and indeed with their blessing. It was a case of belonging to Cambridge as outcome rather than precondition.

Piero Sraffa went to Cambridge for the first time in 1921 to meet Keynes, then famous as the author of The Economic Consequences of the Peace, and in 1927 he came to establish himself in the university city, where he lived until his death in 1983.

He was born in Italy in 1898, in a family well connected with the academic, entrepreneurial, and judicial spheres of Italian society. His fatherAngelo Sraffa-was a professor of commercial law, rector of a private university devoted mainly to commercial studies (the University Luigi Bocconi), and a successful lawyer. In this sense the family background of Piero Sraffa was not very different from that of our group of Cambridge economists: they all came from the educated European bourgeoisie. An important difference in Sraffa's upbringing, however, lies in the fact that boarding schools in Italy were not as important as in Britain in the education of the young and that, in general, young people in Italy tended to leave their families much later than in Britain-in fact Sraffa lived with his parents for most of the time he spent at school and university and continued to do so afterward.

But Sraffa's family proved important for his academic education also, in the peculiar sense that it attenuated significant differences between the Italian and British (or Cambridge) systems of academic education. Although there was nothing in Italy like an economics tripos (which Sraffa would probably have chosen), and although economics was studied only within the faculties of law or in institutions devoted to commercial studies (like the Bocconi University), and there was no supervision (except, to a certain extent, in the case of the final dissertation necessary to get a degree), Piero Sraffa had from his childhood benefited from his father's habit of discussing with him cases of the commercial behavior of firms, while as a university student, he enjoyed the advantage of the personal tuition of one of his father's friends - and indeed one of the most outstanding Italian economists of the time, Attilio Cabiati. In this respect Sraffa's 
background had some affinity with Keynes's, whose first tutor was his father, Neville Keynes.

The fact that Sraffa's father asked Cabiati to monitor and tutor his son's study of economics ${ }^{24}$ gives us the cue to bring politics into our discussion, and to stress another difference between Cambridge and Italy, because it seems to hint implicitly at the fact that Sraffa's own approach to economics, in 1919, when in Turin a number of factories were taken under armed control by workers, was heavily influenced by radicalization of his political views in favor of Bolshevist revolution. Some idea of the radicalization of Sraffa's $(1924,106)$ political position may be gathered from a letter he wrote to Antonio Gramsci in the winter of 1923-24, where he recalled that in 1917 he was shaken out of his previous socialist pacifism: "The [present] situation bears a striking resemblance to that of 1916-17, as does my state of mind. . . My political opinions remain unchanged-worse, I have become fixed in them, fixed as I was, until 1917, in the pacifist socialism of 1914-15, from which I was shaken out when I made the discovery, after Caporetto and the Russian revolution of November, that it was precisely the worker-soldiers whose hands held the guns."

The development of Sraffa's political stance was certainly influenced by the place where he received his higher education. Milan and Turin, unlike Cambridge, were important industrial cities, where the social and economic realities of the time were close at hand and could be appreciated practically through direct experience - and not just intellectual inquiryeven by a young man from a family of the upper bourgeoisie. In Turin in particular, the revolutionary socialist movement was very active. But while in Cambridge a socialist society, although "fairly small and its discussions mainly theoretical" (Dobb 1978, 116), was active in the university, Italian universities offered no established forum of political discussion open to the Left. However, a young socialist student could find a place where politics could be debated in the very premises of the workers' union..$^{25}$

24. In a letter of 22 May 1919 to Attilio Cabiati, Angelo Sraffa said the following: "I put my son under your Paretian protection" (Archivio Fondazione Luigi Einaudi in Torino, Italy, Papers of Attilio Cabiati; Naldi's translation from the Italian).

25. In fact, we know that the Gruppo socialista studentesco used to meet at the Camera del lavoro (centers for the labor movement), and that Sraffa was one of its members. Furthermore Sraffa, then twenty-one, had been introduced in Turin in 1919 to Antonio Gramsci-already a prominent figure of the revolutionary socialist movement-by one of his former secondary school teachers, Umberto Cosmo. 
The 1921 meeting with Keynes turned out to be very important to the life both of Sraffa and of Cambridge, and in 1927 Sraffa accepted a threeyear appointment as lecturer in that university. Once in Cambridge, Sraffa was hosted by Keynes at the very heart of Cambridge's human geography. On his arrival he was given high table rights at King's College and was allowed to live in the college (later he rented a nearby flat owned by King's); he was admitted to Keynes's Political Economy Club and was asked to give papers at the club and to the Emmanuel Economics Society, and, although he delayed his debut as academic lecturer, most probably started his activity as student supervisor. Invited to enter into these elements of the human geography of the place, he was able to become part of Cambridge life from the outset. A consequence of this sort of access soon materialized in terms of what we believe was one of the most important facets of life both for Sraffa and for Cambridge: friendship and informal intellectual relationships. As we all know, Sraffa became a very close friend of Keynes, but on his arrival in Cambridge true friendship also awaited him in the persons of the young physicist Patrick Blackett; Maurice Dobb (whom he had actually known since his first visit to London, in 1921-22); the professor of Italian and philosopher Raffaello Piccoli; and Ludwig Wittgenstein.

In October 1928 Sraffa started his lecture courses, and his position in Cambridge University gradually gained in solidity (see Marcuzzo 2005). Nevertheless, Sraffa always maintained a detachment from the university and the college system. First of all, life in Cambridge left a lot of time to do research on one's own, and Sraffa embraced the opportunity. Second, Sraffa also took full advantage of the possibility of spending the vacations outside the university-in general in Italy. Third, for several years he appears to have been subject to strong centrifugal forces: in 1931 he resigned his lectureship; in 1933 he resigned his librarianship; between 1932 and 1935 he tried to get a Rockefeller grant to spend in Italy or the United States (see Naldi 2005a); in 1935, when he was offered the post of assistant director of research, he caused a lot of trouble to his friendsKeynes, in the first place, but also Robertson-who were involved in negotiations with the general board of the university and were trying to persuade Sraffa to accept the post. Typically, when he was offered a fellowship by Trinity College in 1938, he anguished over the decision. He finally resolved to accept the offer, and probably from that moment his ambivalence toward Cambridge subsided. 
Keynes and the various friends Sraffa had made always managed to keep him in Cambridge and allowed his talents to achieve fruition. Sraffa became and remained part of the group of Cambridge economists and indirectly contributed to their work and that of other Cambridge scholars. In fact, he was regarded a most competent critic, and most probably any piece of economic theory produced in Cambridge was submitted to him for detailed criticism. Cambridge highly valued such work, and also appreciated informal contributions emerging from casual meetings and conversations, like the contributions of Sraffa acknowledged by Wittgenstein in his preface to his Philosophical Investigations, or like those that led to the preparation of Sraffa and Keynes's joint introduction to Hume's Abstract.

Yet Cambridge, as we have already seen, was also able to allow Sraffa to develop a very important part of his own research on a subject somewhat remote from what was being discussed in Cambridge (or indeed anywhere in the world) in the 1930s and 1940s. In fact, after having presented to Keynes and Pigou, in 1927-28, the basic propositions of the research that was to lead to the 1960 publication of Production of Commodities by Means of Commodities (later at the center of the Cambridge capital controversies), Sraffa seems to have discussed the content and the progress of this work in Milan only with his Italian friend Raffaele Mattioli, and in Cambridge only with mathematicians whose help he needed to solve some analytical problems (Kurz and Salvadori 2001, 2005). This, too, may be seen as an instance of the way Cambridge nurtured research for someone who, like Sraffa, came to it as a foreigner, an émigré, and a true outsider.

\section{Tentative Conclusions}

The place Cambridge seems to us important for the formation of these economists' group identity for a number of reasons, which we list here as tentative and provisional conclusions.

Through personal relations and a certain lifestyle (the college-oriented life of the don), the transmission of ideas took on a very particular formcentered on the tutorial system, exchanges in writing, and the debating societies' style of comparing and contrasting certain positions.

The group's system of values cemented their sense of militancy as economists, which was more important to them than academic and professional success. In a 2 October 1986 interview with Maria Cristina Marcuzzo, 
Austin Robinson recalled that "in the 1920s we were all 'good-doers,' and we wanted to change the world."

The intellectual, academic, and personal unconventionality that find such striking exemplification in the biographies of Keynes, Sraffa, and Joan Robinson in particular was more readily accepted in Cambridge than in any other center in the history of economic thought, and such unconventionality is the most distinctive mark of what it meant to be part of it.

\section{References}

Becattini, G. 1990. Alfred Marshall e la vecchia scuola economica di Cambridge. In Il pensiero economico: Temi, problemi e scuole, edited by G. Becattini, 275-310. Turin: Utet.

Besomi, D. 2000. On the Spread of an Idea: The Strange Case of Mr. Harrod and the Multiplier. HOPE 32:347-79.

Coats, A. W. 1967. Sociological Aspects of British Economic Thought (ca. 1880-1930). Journal of Political Economy 75:706-29.

- 1993. The Sociology and Professionalization of Economics. Vol. 2 of British and American Economic Essays. London: Routledge.

Collard, D. A. 1990. Cambridge after Marshall. In Centenary Essays on Alfred Marshall, edited by J. K. Whitaker, 164-92. Cambridge: Cambridge University Press.

Dobb, M. 1928. Wages. Cambridge Economic Handbook 6. London: Nisbet.

- 1978. Random Biographical Notes. Cambridge Journal of Economics 2:115-20.

Eatwell, J., and C. Panico. 1987. Sraffa, Piero. In vol. 4 of The New Palgrave: A Dictionary of Economics, edited by J. Eatwell, M. Milgate, and P. Newman, 445-52. London: Macmillan.

Groenewegen, P. 1995. A Soaring Eagle: Alfred Marshall, 1842-1924. Aldershot: Elgar.

Hamouda, O. F. 1993. John R. Hicks: The Economist's Economist. Oxford: Blackwell.

Harrod, R. F. 1951. The Life of John Maynard Keynes. London: Macmillan.

- 2003. Correspondence, 1919-35. Vol. 1 of The Collected Interwar Papers and Correspondence of Roy Harrod, edited by D. Besomi. Cheltenham: Edward Elgar.

Hicks, J. R. 1939. Value and Capital: An Inquiry into Some Fundamental Principles of Economic Theory. Oxford: Clarendon Press.

- 1982. A Note on Robertson. In Money, Interest, and Wages, 127-31. Vol. 2 of Collected Essays on Economic Theory. Cambridge, Mass.: Harvard University Press.

Johnson, E., and H. G. Johnson, eds. 1978. The Shadow of Keynes: Understanding Keynes, Cambridge, and Keynesian Economics. Oxford: Basil Blackwell. 
Johnson, H. G. 1978a. Cambridge as an Academic Environment in the Early NineteenThirties: A Reconstruction from the Late Nineteen-Forties. In Johnson and Johnson 1978, 84-105.

1978b. Cambridge in the 1950s. In Johnson and Johnson 1978, 127-50.

Kahn, R. F. Papers. Modern Archives, King's College, University of Cambridge. 1937. The Problem of Duopoly. Economic Journal 47:1-20.

- 1989. The Economics of the Short Period. London: Macmillan.

Kaldor, Nicholas. Papers. Modern Archives, King's College, University of Cambridge.

Keynes, J. M. Papers. Modern Archives, King's College, University of Cambridge.

- 1936. The General Theory of Employment, Interest, and Money. London: Macmillan.

- 1978. Activities 1922-1932: The End of Reparations. Vol. 18 of The Collected Writings of John Maynard Keynes, edited by D. Moggridge. London: Macmillan.

Kurz, H., and N. Salvadori. 2001. Sraffa and the Mathematicians: Frank Ramsey and Alister Watson. In Piero Sraffa's Political Economy: A Centenary Estimate, edited by T. Cozzi and R. Marchionatti, 254-84. London: Routledge.

- 2005. Removing an "Insuperable Obstacle" in the Way of an Objectivist Analysis: Sraffa"s Attempts at Fixed Capital. European Journal of the History of Economic Thought 12:493-523.

Lavington, F. 1922. The Trade Cycle: An Account of the Causes Producing Rhythmical Changes in the Activity of Business. London: P.S. King \& Son.

Leontief, W. 1937. Implicit Theorizing: A Methodological Criticism of the NeoCambridge School. Quarterly Journal of Economics 51:337-51.

Marcuzzo, M. C. 2005. Piero Sraffa at the University of Cambridge. European Journal of the History of Economic Thought 12:425-52.

- 2006. Keynes and Cambridge. In The Cambridge Companion to Keynes, edited by R. E. Backhouse and B. W. Bateman, 118-35. Cambridge: Cambridge University Press.

Marcuzzo, M. C., and A. Rosselli, eds. 2005. Economists in Cambridge, 1907-1946: A Study through Their Correspondence. New York: Routledge.

Marcuzzo, M. C., and E. Sanfilippo. 2008. Dear John, Dear Ursula (Cambridge and LSE, 1935): Eighty-Eight Letters Unearthed. In Markets, Money, and Capital: Hicksian Economics for the 21st Century, edited by R. Scazzieri, A. K. Sen, and S. Zamagni. Cambridge: Cambridge University Press.

Marcuzzo, M. C., and E. Sanfilippo, with T. Hirai and T. Nishizawa, eds. 2006. The Letters between John Hicks and Ursula Webb, September-December 1935. Working paper no. 207, Kobe, University of Hyogo.

Marshall, A. 1902. A. Marshall on Economics for Business Men. Journal of Political Economy 10.3:429-37.

- 1919. Industry and Trade. London: Macmillan.

- 1923. Money, Trade, and Commerce. London: Macmillan. 
Moggridge, D. E. 1992. Maynard Keynes: An Economist's Biography. London: Routledge.

Naldi, N. 2000. Piero Sraffa and Antonio Gramsci: Their Friendship between 1919 and 1927. European Journal of the History of Economic Thought 7:79-114.

— 2005a. Piero Sraffa: Emigration and Scientific Activity (1921-1945). European Journal of the History of Economic Thought 12:379-402.

- 2005b. Robertson and the Great Divide. The Correspondence with Kahn, Kaldor, J. Robinson, and Sraffa. In Marcuzzo and Rosselli 2005, 371-87.

Nishizawa, T. 2004. The Economics Tripos and the Marshallian School in the Making. Economic Review 55:358-78.

Pasinetti, L. 2007. Keynes and the Cambridge Keynesians. Cambridge: Cambridge University Press.

Pigou, A. C. 1927. Industrial Fluctuations. London: Macmillan.

Plumptre, A. F. W. 1975. Maynard Keynes as a Teacher. In Essays on John Maynard Keynes, edited by Milo Keynes, 247-53. Cambridge: Cambridge University Press.

Reder, M. W. 1982. Chicago Economics: Permanence and Change. Journal of Economic Literature 20:1-38.

Robertson, D. H. 1923. The Control of Industry. London: Nisbet. 1926. Banking Policy and the Price Level. London: P. S. King.

Robinson, E. A. G. 1941. Monopoly. London: Nisbet.

- 1977. Keynes and his Cambridge Colleagues. In Keynes, Cambridge, and the General Theory, edited by D. Patinkin and J. C. Leith, 25-38. London: Macmillan.

- 1992. My Apprenticeship as an Economist. In Eminent Economists: Their Life Philosophies, edited by M. Szenberg, 203-21. Cambridge: Cambridge University Press.

Robinson, J. 1933. The Economics of Imperfect Competition. London: Macmillan.

Rosselli, A. 2005. The Defender of the Marshallian Tradition: Shove and the Correspondence with Kahn, J. Robinson, and Sraffa. In Marcuzzo and Rosselli 2005, 350-70.

Rosselli, A., and D. Besomi. 2005. The Unlooked for Proselytiser: J. Robinson and the Correspondence with Sraffa, Harrod, and Kaldor. In Marcuzzo and Rosselli 2005, 309-27.

Sanfilippo, E. 2005. Keynes's Valuable Opponent and Collaborator: The Correspondence between Keynes and Robertson. In Marcuzzo and Rosselli 2005, 58-74.

Shove, G. F. 1933. The Imperfection of the Market. Economic Journal 43:113-24.

Skidelsky, R. 1983. Hopes Betrayed, 1883-1920. Vol. 1 of John Maynard Keynes: A Biography. London: Macmillan.

- 1992. The Economist as Saviour, 1920-1937. Vol. 2 of John Maynard Keynes: A Biography. London: Macmillan.

Sraffa, P. Papers. Wren Library, Trinity College, University of Cambridge. 1924. Problemi di oggi e di domani. L'ordine nuovo (1-15 April): 4. English translation in Naldi 2000, 106-7. 
- 1925. Sulle relazioni fra costo and quantità prodotta. Annali di economia 2:277-328.

. 1926. The Laws of Returns under Competitive Conditions. Economic Journal 36:535-50.

- 1960. Production of Commodities by Means of Commodities. Cambridge: Cambridge University Press.

Thirwall, A. 1987. Nicholas Kaldor. Brighton: Wheatsheaf Books.

Tribe, K. 1997. Introduction. In Economic Careers: Economics and Economists in Britain, 1930-1970, edited by K. Tribe. London: Routledge.

- 2008. British Economics in the Twentieth Century. In The New Palgrave Dictionary of Economics, edited by S. Durlauf and L. Blume. 2nd. ed. Basingstoke: Palgrave Macmillan.

Waterman, A. M. C. 2003. Joan Robinson as a Teacher. Review of Political Economy 15:589-96. 
